\title{
Climate change? When? Where?
}

\author{
Helen Boon \\ James Cook University
}

\begin{abstract}
Regional Australian students were surveyed to explore their understanding and knowledge of the greenhouse effect, ozone depletion and climate change. Results were compared with a parallel study undertaken in 1991 in a regional UK city.

The comparison was conducted to investigate whether more awareness and understanding of these issues is demonstrated by students as a result of over 16 years' accumulated knowledge, increased certainty among experts of greenhouse effects on climate, media publicity and inclusion of the greenhouse effect in the Australian school curriculum.
\end{abstract}

Data obtained from a combined sample of 740 Year 8/10 secondary students examined the extent of student understanding and knowledge, models of explanation and sources of information of the phenomena. A path analytic, Structural Equation Model (SEM) tested links between student understanding of the greenhouse effect, knowledge of greenhouse gases and experience of being in a greenhouse, to conceptions of climate change.

Results show similarities between the two groups, with knowledge and understanding of these important scientific literacy issues remaining unacceptably low in 2007. Sociocultural influences are proposed in relation to results and implications for practice are suggested.

According to Lowe (2000), the Australian government, supported by industry interest lobbies such as the coal producers, showed reluctance to adopt policies to mitigate greenhouse effects upon the climate, meeting with little opposition from the public. Is the reason for this public indifference, lack of knowledge? Until the election of the new federal government in 2007 which resulted in a change in Australia's political stance on climate change, failure to ratify the Kyoto Protocol sent mixed messages to business (Papadakis, 2002) and possibly to educators. These ambiguous messages interact to shape people's beliefs and values which then directly affect how current knowledge is used (e.g., Massarani \& Castro Moreira, 2005). 
In teaching environmental issues such as the greenhouse effect and ozone layer depletion it is inevitable that discussions about individual response will arise from students; these discussions might be value laden. Climate politics are among the most controversial on the international arena, as evidenced by debates surrounding ratification of the Kyoto protocol. Climate change involves issues ranging from burden-sharing between countries with widely differing economic vulnerabilities and adaptabilities to climate change, to choices made by individuals about everyday energy consumption, power use and transportation. Asking governments and consumers to make major sacrifices to benefit future generations is not just a problem requiring extreme altruism it could also be expensive. The dilemma facing educators must be, then, how to ensure they educate their students so they are scientifically literate without compromising their personal and political views.

Much has been written world-wide (see for example Ryder, 2001) and in Australia about scientific literacy and its importance for the informed participation of citizens (Tytler, 2007). However, based on findings reported here, this article contends that climate change understanding, a pressing environmental issue and scientific literacy concept, needs elaboration in regional Australians classrooms and greater emphasis in syllabus documents.

Boyes and Stanisstreet (1993) stated that the greenhouse effect has been cited as "perhaps the most important and widely reported problem in recent times" (p. 531). Evidence of climate change due to human activity, particularly the combustion of fossil fuels since the industrial revolution, has been collected for some years. "Global Greenhouse Gas emissions due to human activities have grown since pre-industrial times, with an increase of 70\% between 1970 and 2004" (Intergovernmental Panel on Climate Change (IPCC), 2007, p. 4). Consequences of higher average temperatures due to the greenhouse effect such as rises in sea level, desertification, extinction of plant and animal species, shifting of agricultural patterns and increased frequencies in extreme weather phenomena such as cyclones are now considered unequivocal by the scientific community (IPCC, 2007) with very few divergent views (e.g., Khilyuk \& Chilingar, 2003). A question then is raised: is this important concept being taught adequately, if at all, and are students, our future citizens, acquiring an understanding of the phenomenon? The importance of understanding this lies in its impact (or not) upon environmental attitudes and behaviour, behaviour that radiates through individuals, to local communities, to national policies and international agreements.

Evidence shows sectors of the Australian community (education, industry, university, government) value knowledge of science, or scientific literacy, for the public understanding of, and response to, issues affecting societies (e.g., Tytler \& Symington, 2006). Knowledge and understanding of the greenhouse effect and climate change, 
though deemed necessary, has historically been inadequate for informed citizenship. Researchers have examined public knowledge of two sometimes conflated phenomena, the greenhouse effect and ozone depletion. Lay people in Canada, USA, Mexico, Brazil, Portugal and Russia saw global warming as a problem, though not as serious as ozone depletion and most acknowledged that they did not understand it very well (Dunlap, 1998). Other studies reported similar findings in the US (Berk \& Schulman, 1995; Fortner et al., 2000). US college students demonstrated similar misconceptions and lack of understanding about the two phenomena (e.g., Wilson \& Henson, 1993; Morgan \& Moran, 1995; Kerr \& Walz, 2007). This was also the case for UK college students (Jeffries, Stanisstreet, \& Boyes, 2001), while Australian college students' understanding of the role of the ozone layer was inadequate (Cordero, 2001).

The perceived importance of the greenhouse effect appears to be decreasing in the public eye. Environmental issue awareness in general, including the greenhouse effect, was rated in Australia in 1999 (Australian Bureau of Statistics (ABS), 1999). Results placed the greenhouse effect ninth in order of perceived importance after: air pollution (29.1\%), freshwater pollution (24.6\%), ocean/sea pollution (22.4\%), destruction of trees (21.1\%), garbage/rubbish disposal (14.1\%), ozone layer (12.3\%), toxic chemicals/waste (11.0\%), soil erosion/salinity (10.2\%), and greenhouse effect (8.7\%). In 1998, however, the greenhouse effect ranked eighth out of 20 environmental issues (ABS, 1998). The Environmental Protection Authority (EPA) in Australia reported in 2000 that 58\% of respondents to a survey on the greenhouse effect answered incorrectly when asked "Is the greenhouse effect caused by the hole in the atmosphere?" a two percent increase since 1994. More recently, a survey in Western Australia revealed that $62 \%$ of adults admitted that they were not following the greenhouse gas debate, though whether this was because of lack of interest or understanding was not examined (Terry, 2007). Overall, results imply the majority of those who don't understand the greenhouse effect well are not interested in the issue or choose not to become better informed. This raises important questions about the education activities that the Australian public has been exposed to about the greenhouse effect, the ozone layer and climate change.

Yet scientific literacy appears to be taken seriously, since Australian government education departments have ensured school curricula include content to enhance students' scientific literary. For example, educational policy in Queensland, where the current research project was implemented, has resulted in a science curriculum document for Years 1-10 which includes the greenhouse effect directly within the "Energy and Change" strand. The greenhouse effect is also included within the "Earth and Beyond" strand, under "Caring for the environment, managing human impact on land, water and atmosphere", both core science topics (Queensland Studies Authority (QSA), 2007, p.36, 37). Other States are similar. As early as 1989 the greenhouse effect was included in the NSW curriculum statements (Skamp, 2000). 
International student performance comparisons indicate that in Australia overall, the scientific literacy of students at the end of their compulsory schooling appears to be strong. Specifically, recent data obtained by the Organisation for Economic Cooperation and Development (OECD) (2007) suggests that 15 year old Australian students' proficiency at explaining scientific phenomena is above the OECD average, being in the top five. Additionally, 15 year old Australian students' mean scores for the "Earth and space systems" scale assessed in the Program for International Student Assessment (PISA) study (OECD, 2007) shows them to be in the top four (p. 48), while their mean score for the "Physical systems scale" puts them in the top 12 countries (p. 52). For scientific literacy overall, Australian adolescents were ranked fifth in the OECD countries (OECD, 2007, p. 27). On all counts they were ranked above UK students of the same age (OECD, 2007).

Nonetheless, while the PISA scientific literacy assessment instruments include climate change, it is still not clear from these data how well regional Australian students approaching the end of Year 10, (a critical time because they may, potentially, never opt to study science again) understand the greenhouse effect and climate change, or whether they recognise differences between the greenhouse effect and ozone layer depletion. Many prior studies have shown that the two phenomena are repeatedly conflated by school students (see review by Lee, Lester, Ma, Lambert, \& Jean-Baptiste, 2007; Fisher, 1998), higher education students (Spellman, Field, \& Sinclair, 2003) and student teachers (Dove, 1996). Both phenomena have and will continue to demand community as well as individual responses. Both have been hotly debated in the political arena and have and will continue to divide voters. Because there is empirical evidence that suggests proenvironmental behaviour is predicted by knowledge and education about the issue in debate (Barr, 2007; Weaver, 2002) it is important that voters enter the polling booth with adequate knowledge.

While policies by State Education departments support the teaching of these important concepts, it is not clear how well such policies are enacted. In the UK, Coffield et al. (2007) report "we have not found evidence of the direct or simple transmission of policy into teaching practices ... We also found that some senior management teams, faced with the same policy framework, felt they could exercise more freedom in translating external policy into internal plans and practices" (p. 736). In Australia, science teaching in the compulsory years of schooling is so "flexible" that it might be difficult to examine whether policy has been translated directly into practice. This view is summarised by the perceptions of a British teacher who conducted a small study in Victoria and the ACT to compare Australian students' explanations and conflation of the two phenomena with those of UK students. Fisher (1998) stated that "Schools in Australia, and teachers in classes generally, have a lot more freedom to choose science content than do their British counterparts, particularly so for the age range of up to 16 years" (Fisher, 1998, p. 53). 


\section{Purpose, Methods and Results}

The current study presents data gathered in September 2007 from regional urban Australian secondary students, pre-dating the change of federal government in Australia and data gathered in April 1991 in a regional UK city from a similar cohort. A group of 389, Year 8 and 10 Australian students' ideas about the greenhouse effect, climate change and the ozone layer are compared to results obtained from a parallel unpublished study conducted in 1991 in the UK with 351 students.

The two sets of data are worthy of comparison because they were gathered during periods when in both countries there was a high level of media coverage of the phenomena. Un-seasonal weather patterns and debates in the political sphere prior to National elections (1992 in the UK and 2007 in Australia) raged in news reports and media programmes. John Major, the Conservative party leader, endorsed the following in the British election campaign in November 1990:

One of the most important issues facing all countries is the threat of global warming. Effective action to combat global warming must be international action. Again we have taken a lead . . . We have said that we will consider stabilising our $\mathrm{CO}_{2}$ emissions earlier than our existing conditional target of 2005. (Conservative Party, 1992)

The extent to which students in both countries might have been taught about the two concepts is comparable. The UK data was gathered when Year 10 students were not yet following the National Curriculum for Science, wherein the phenomena are included for study, and therefore they might or might not have been taught about them in school. The Year 8 classes were just beginning the National Curriculum and so were more likely to have been exposed to these topics. By contrast, Queensland students attending state schools at the present time should have been exposed to both phenomena to a degree by the end of Year 10. This is not always the case however because individual Queensland schools are free to select content material for their work programmes to provide "learning experiences and assessment tasks through which students have opportunities to demonstrate what they know and can do in the Years 1-10 Science key learning area" (QSA, 1999, p.8). The strands within the Science key learning area in Queensland are: science and society; earth and beyond; energy and change; life and living and natural and processed materials (QSA, 1999). Climate change also appears in the Key learning area Studies of Society and Environment (SOSE), in the core strand Place and Space, (QSA, 2000, p. 41). In short, this study examines the extent to which secondary students in the two countries are familiar with concepts that are critical for their development of scientific literacy in political climates and education frameworks that are approximately comparable, despite a 16-year separation in time. 


\section{Study aims}

It was hypothesised that student knowledge about the greenhouse effect and the role of the ozone layer would be more accurate in 2007 than in 1991, based on the assumption that the large body of evidence gathered by the scientific community to date (IPCC, 2007) will have been passed down to teachers training in higher education institutions and then on to students in schools.

The original 1991 study examined:

- The knowledge students had of climate change, its causes and consequences.

- Models of explanation constructed by students concerning climate change and the Greenhouse Effect.

- Conflation of ideas between climate change and the role played by the ozone layer.

- The source of students' ideas.

The same issues were investigated in the 2007 study in order to compare and contrast the two groups. In addition, structural equation modelling (SEM) is used to assess a model postulating that knowledge of the greenhouse effect predicts correct ideas about climate change in Australian students. Model 1 is tested to examine links, if any, between various ideas.

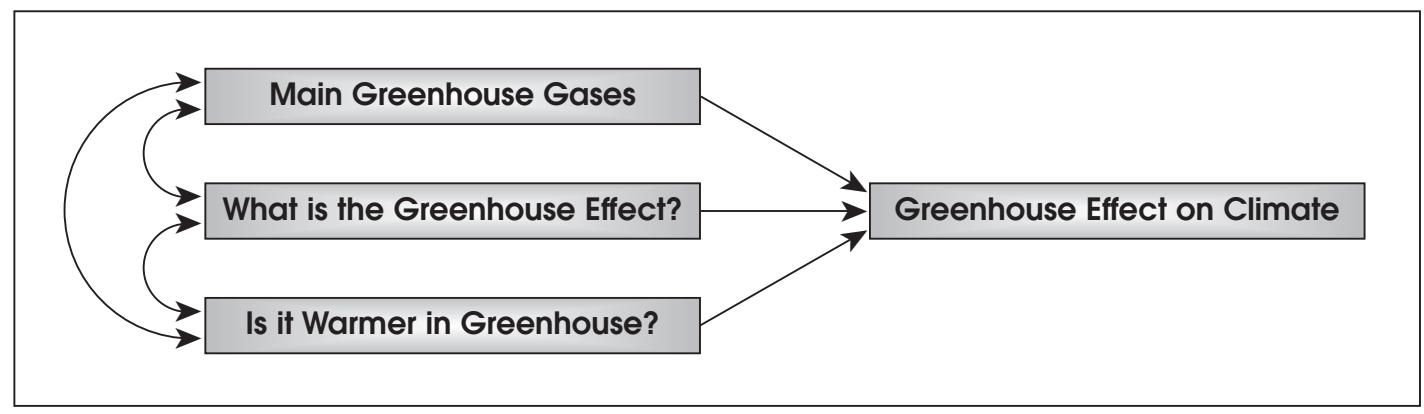

Figure 1: Theoretical Model:

Influences guiding the perceptions of the greenhouse effect upon climate change

SEM is very useful for simultaneously modelling multiple predictor variables (and graphically representing their relative contribution to the outcome variable), resulting in a more accurate weighting of influences for a particular outcome. This is not possible with association tests preformed for each predictor (MacCallum \& Austin, 2000). SEM also helps to overcome the problems associated with the effects of 
measurement error and correlated measurement error on the outcome variable (Baron \& Kenny, 1986) which attenuate the estimation of relationships between observed variables (Maruyama, 1998). Moreover, SEM techniques developed over the last two decades permit the use of dichotomous categorical predictor variables in a model without the need to employ more complicated logistic regression models (Joreskog \& Sorbom, 1984; Muthen, 1984). Where data is not continuous, as in the data used here, SEM provides a valuable analytical tool by permitting the use of dichotomous variables. The assumption of multivariate normality need not apply to the exogenous (measured) variables (Bollen, 1989, pp. 126-28).

\section{Methods}

The 1991 study involved 168 Year 10 and 183 Year 8 students derived from two state schools selected at random in a northern UK city. The 2007 cohort comprised a total of 389 students; 79 Year 8 students and 310 Year 10 students derived from four state schools selected at random in a Queensland regional city. There were 188 males and 201 females in the Australian group and 189 males and 162 females in the UK group. The completion of the questionnaire was anonymous and voluntary and students were free to omit any questions that they did not want to answer. The questionnaire (Appendix 1) was completed during regular science classes with the students' usual science teacher. Two pilot questionnaires were written, each consisting of different questions, and these were tested on a class of Year 8 students at School One in the UK. Student responses were examined and the most suitable questions from the two trial surveys were selected for the final survey. Small amendments were made to the wording of some of the questions. The only differences between the original 1991 questionnaire and the 2007 version is the addition of the "internet" as a source of ideas, in question seven and a question about ethnicity in the personal section (Indigenous/non-Indigenous). A total of 15 classes in the Year 8 and 10 groups participated in the two UK schools, representing a 90\% participation rate; 18 classes in Year 8 and 10 participated in the four Australian schools, reflecting an 80\% participation rate, providing a wide cross-section of age and ability. For use with SEM techniques all data was dichotomised, with correct answers coded (1) and others coded (0).

\section{Results}

The SPSS 14 programme (SPSS, Chicago, IL) was used to perform all statistical procedures while the structural equation path models (SEM) were developed using the AMOS 6.0 programme (Arbuckle \& Wothke, 1999). 


\section{HELEN BOON}

Table 1 presents a summary of all results obtained through questions 1-6, by year and by country, being responses regarded as the accepted scientific answers, i.e., correct answers. Analyses of variances (ANOVAs) were conducted for the four groups; results are displayed in Table 1.

\begin{tabular}{|c|c|c|c|c|c|c|c|c|}
\hline \multirow[b]{2}{*}{ Survey questions 1-6 } & \multicolumn{3}{|c|}{ Australian } & \multicolumn{3}{|c|}{ UK } & \multirow{2}{*}{$\begin{array}{c}\text { Wilk's } \\
\text { lambda, } \\
F(3,736)\end{array}$} & \multirow{2}{*}{$\begin{array}{l}\text { Size } \\
\text { effect } \\
\left(\eta p^{2}\right)\end{array}$} \\
\hline & $\overline{\operatorname{Yr} 8 \%(n)}$ & Yr $10 \%(n)$ & Total \% (n) & $\overline{\operatorname{Yr} 8 \%(n)}$ & Yr $10 \%(n)$ & Total \% (n) & & \\
\hline Is it warmer inside a greenhouse? & $43.0(34)$ & $41.0(127)$ & $41.4(161)$ & $87.4(160)$ & $100(168)$ & $93.4(328)$ & $110.22^{* *}$ & .31 \\
\hline Why is it warmer in a greenhouse? & $43.0(34)$ & $14.5(45)$ & $20.3(79)$ & $26.8(49)$ & $38.7(65)$ & $32.5(114)$ & $16.71^{\star *}$ & .06 \\
\hline $\begin{array}{l}\text { Which are the main greenhouse } \\
\text { gases? }\end{array}$ & $82.3(65)$ & $82.3(255)$ & $82.3(320)$ & $67.8(124)$ & $75.0(126)$ & $71.2(250)$ & $5.18^{*}$ & .02 \\
\hline Other greenhouse gases? & $15.2(12)$ & $12.9(40)$ & $13.4(52)$ & $13.7(25)$ & $25.6(43)$ & $19.4(68)$ & $4.84^{*}$ & .02 \\
\hline Greenhouse effect-what is it? & $12.7(10)$ & $14.5(45)$ & $14.1(55)$ & $10.9(20)$ & $14.9(25)$ & $12.8(45)$ & .54 & .002 \\
\hline $\begin{array}{l}\text { Impact of greenhouse effect on } \\
\text { climate }\end{array}$ & $55.7(44)$ & $55.8(173)$ & $55.8(217)$ & $65.6(120)$ & $76.2(128)$ & $70.7(248)$ & $7.41^{\star *}$ & .03 \\
\hline Effects on sea levels & $81.0(64)$ & $74.2(230)$ & $75.6(294)$ & $67.8(124)$ & $63.1(106)$ & $65.5(230)$ & $3.82^{*}$ & .02 \\
\hline Effects on rainfall & $44.3(35)$ & $50.3(156)$ & $49.1(191)$ & $23.5(43)$ & $32.1(54)$ & $27.6(97)$ & $13.83^{\star *}$ & .05 \\
\hline Effects on sunshine & 24.1 (19) & $25.2(78)$ & $24.9(97)$ & $12.0(22)$ & $20.8(35)$ & $16.2(57)$ & $4.26^{*}$ & .02 \\
\hline Effects on farmer's crops & 74.7 (59) & $73.5(228)$ & $73.8(287)$ & $63.9(117)$ & $70.2(118)$ & $67.0(235)$ & 1.96 & .01 \\
\hline Effects on ice caps & $79.7(63)$ & $86.1(267)$ & $84.8(330)$ & $85.2(156)$ & $85.1(143)$ & $85.2(299)$ & .68 & .003 \\
\hline $\begin{array}{l}\text { Burning oil or coal effects on } \\
\text { greenhouse gases }\end{array}$ & $78.5(62)$ & 80.3 (249) & $79.9(311)$ & $69.4(127)$ & $83.3(140)$ & $76.1(267)$ & $3.94^{*}$ & .02 \\
\hline $\begin{array}{l}\text { Planting trees/forests effects on } \\
\text { greenhouse gases }\end{array}$ & $77.2(61)$ & $78.4(243)$ & $78.1(304)$ & $71.0(130)$ & $81.5(137)$ & $76.1(267)$ & 2.00 & .01 \\
\hline CFC's effects on greenhouse gases & $46.8(37)$ & $45.8(142)$ & $46.0(179)$ & $63.9(117)$ & $82.1(138)$ & $72.6(255)$ & $24.01^{\star \star}$ & .09 \\
\hline $\begin{array}{l}\text { Alternative energy sources use and } \\
\text { effects on greenhouse gases }\end{array}$ & $68.4(54)$ & $72.9(226)$ & $72.0(280)$ & $66.1(121)$ & $76.8(129)$ & $71.2(250)$ & 1.87 & .01 \\
\hline $\begin{array}{l}\text { Insulating buildings effects on } \\
\text { greenhouse gases }\end{array}$ & $51.9(41)$ & $56.8(176)$ & $55.8(217)$ & $55.7(102)$ & $60.7(102)$ & $58.1(204)$ & .63 & .003 \\
\hline $\begin{array}{l}\text { Using motor cars effects on } \\
\text { greenhouse gases }\end{array}$ & $72.2(57)$ & $76.1(236)$ & $75.3(293)$ & $73.2(134)$ & $83.9(141)$ & $78.3(275)$ & 2.39 & .01 \\
\hline Have you heard of the ozone layer? & $83.5(66)$ & $88.7(275)$ & $87.7(341)$ & $95.1(174)$ & $94.0(158)$ & $94.6(332)$ & $4.35^{*}$ & .02 \\
\hline What does the ozone layer do? & $21.5(17)$ & $17.7(55)$ & $18.5(72)$ & $53.0(97)$ & $66.1(111)$ & $59.3(208)$ & $55.74^{\star \star}$ & .19 \\
\hline
\end{tabular}

Note: * $p<01$ *** $p<001$

Partial Eta squared, $\left(\eta_{\mathrm{p}}{ }^{2}\right)$ accounts for the effect of an independent variable upon a dependent one (Pierce, Block, \& Aguinis, 2004). Values of .01, .06 and .14 represent small, medium and large sizes respectively.

\section{Table 1: Correct answers to questions 1-6 by year and location}

Results indicate all groups are equally uncertain about what the greenhouse effect actually is. The UK students were much clearer about the higher temperature inside a greenhouse than their Australian counterparts, perhaps because Australians do not generally use glass greenhouses in the Tropics. Differences in student responses about why it is hotter inside a greenhouse were not as marked, though statistically significant: $32.5 \%$ of the UK students answered correctly compared to only $20.3 \%$ of Australian students $\left(\eta_{\mathrm{p}}^{2}=.06\right.$, medium size effect (Pierce, Block, \& Aguinis, 2004)). However, the most notable difference between the two groups was their appreciation of the connections between the greenhouse effect and climate change. Correct Australian responses were significantly lower than those of the UK cohort $(55.8 \%$ and $70.7 \%$ respectively, $\eta_{\mathrm{p}}{ }^{2}=.03$ ). Students' knowledge about the effects of climate change showed different patterns. All groups performed equally on what might happen to the ice caps and farmers' crops, with Australian students significantly clearer about effects on rainfall $\left(\eta_{\mathrm{p}}{ }^{2}=.05\right)$, sea levels $\left(\eta_{\mathrm{p}}{ }^{2}=.02\right)$ and sunshine levels 
$\left(\eta_{\mathrm{p}}{ }^{2}=.02\right)$. Reasons for this may be that there is more scientific consensus about climate change ramifications now than in 1991.

\begin{tabular}{|c|c|c|}
\hline Why is it hotter in a greenhouse? & $\begin{array}{c}\text { UK students } \\
\text { Year } \mathbf{8} / \mathbf{1 0}(\mathbf{\%})\end{array}$ & $\begin{array}{c}\text { Australian students } \\
\text { Year } \mathbf{8 / 1 0}(\mathbf{\%})\end{array}$ \\
\hline Don'† know & 4.0 & 54.6 \\
\hline Heat not allowed to escape & 24.0 & 15.7 \\
\hline Air not allowed to escape & 28.0 & 4.1 \\
\hline Sun rays trapped & 6.0 & 1.3 \\
\hline Glass magnifies Sun's heat & 21.0 & 0.8 \\
\hline Glass reflects Sun's heat & 7.0 & 0.0 \\
\hline Confused /Cooler (Australian students) & 10.0 & 4.9 \\
\hline Humidity inside greenhouse & 0.0 & 6.2 \\
\hline Insulation/type of materials affect temperature & 0.0 & 5.4 \\
\hline Plants affect temperature inside greenhouse & 0.0 & 3.1 \\
\hline Pollution, ozone, greenhouse gases, U.V. rays & 0.0 & 3.9 \\
\hline
\end{tabular}

Table 2: Why is it hotter in a greenhouse?

Percentage and type of model of explanation used by UK and Australian students

\begin{tabular}{|c|c|c|}
\hline What is the greenhouse effect? & $\begin{array}{c}\text { UK students } \\
\text { Year 8/10 (\%) }\end{array}$ & $\begin{array}{c}\text { Australian students } \\
\text { Year 8/10 (\%) }\end{array}$ \\
\hline Correct & 12.8 & 14.1 \\
\hline Don't know & 20.0 & 30.1 \\
\hline Warming of the climate & 9.0 & 14.4 \\
\hline Warming due to ozone layer & 5.0 & 3.0 \\
\hline Gases affecting ozone layer & 11.0 & 9.0 \\
\hline Hole in ozone layer causing warming & 16.0 & 1.0 \\
\hline Caused by carbon dioxide & 3.2 & 1.0 \\
\hline Gases insulating the earth & 4.0 & 12.4 \\
\hline Carbon dioxide can't escape & 2.0 & 0.0 \\
\hline Others & 17.0 & 4.5 \\
\hline Media hype & 0.0 & 4.5 \\
\hline Pollutant gases & 0.0 & 6.0 \\
\hline
\end{tabular}

Table 3: Percentage and type of model of explanation used about the greenhouse effect by student group

Assessment of human activity and its impact showed two statistically significant differences: post hoc (Bonferroni correction) comparisons showed Year 8 UK students knowledge of the impact of coal and oil burning on greenhouse gas emission was significantly lower than the other three groups (Table $1,\left(\eta_{\mathrm{p}}{ }^{2}=.02\right)$ ), reflecting curriculum development of energy issues in later year levels. UK students' knowledge 
about CFC use and manufacture was significantly better $\left(\eta_{\mathrm{p}}{ }^{2}=.09\right.$, large size effect), possibly because there was more media exposure to this issue during those times than lately. This may also be the reason why the UK students' understanding of the function of the ozone layer was significantly better than the knowledge of current Australian students, with a large size effect $\left(\eta_{\mathrm{p}}{ }^{2}=.19\right)$.

Students' qualitative explanations about why it is hotter inside a greenhouse show a constructivist principle in action i.e. ideas already constructed by the learner, facilitating the acquisition and development of new concepts (Driver, Asoko, Leach, Mortimer, \& Scott, 1994) since their explanations link with their everyday experiences. UK students' ideas reflect their experience with glass greenhouses (Table 2) whereas Australian students, unfamiliar with glass greenhouses (54.6\% said "Don't know"), construct their explanations with more familiar ideas such as humidity, insulation materials, and plant action to raise temperatures in greenhouses (which some students thought were made of green material that attracted more heat). Current Australian students' preoccupation with computer games and indoor activities, to avoid sunburn in Queensland, manifest themselves in a lack of experience with outdoor experiments with sunlight and glass prisms/magnifying glasses, a likely source of explanations for $21 \%$ and $7 \%$ of UK students.

The conceptual models students use to explain their ideas about the greenhouse effect are similar (Table 3). The Australian group included "Media hype" and "Pollutant gases", distinct from carbon dioxide, as potential explanations.

Although explanations are similar, Australian students use more general explanation models in some instances (pollution, warming of the climate), while their apparently limited knowledge of the hole in the ozone layer makes a smaller contribution to their construction of understanding of the greenhouse effect (1\%) compared to UK students. The appearance of Media hype in their explanation and the large proportion of Don't know (30.1\%) may signify engagement with the political stance that Australia had hitherto undertaken on the matter.

Conflation of ideas about the ozone layer and the greenhouse effect appear to persist in students though in somewhat different, less specific terms than they did in 1991. Student comments about the function of the ozone layer (e.g., it keeps the air inside the planet; protects the earth's surface from extreme heat from the Sun; keeps all the gases and oxygen inside the earth; it is a blanket around the Earth) suggest that they have an idea that it protects the Earth from something important, although what that is, appears very hazy in most Australian students' minds. 
The question that is difficult to answer from these results is to what extent the students' understanding of the greenhouse effect is the basis of their knowledge of climate change. In order to examine whether climate change knowledge was predicted by knowledge about the greenhouse effect, the main greenhouse gases and the appreciation that it is warmer inside a greenhouse than outside, data was modelled into theoretical Model 1. Models were estimated by full information maximum likelihood estimation (FIML) with missing data (Arbuckle \& Wothke, 1999). Obtained SEM fit statistic is $\chi^{2}=0(d f=0)$ (since the model is a fully saturated regression model and probability $(p)$ therefore cannot be computed as with all saturated models (E. Cunningham, personal communication, November 12, 2008). The fitted model (Figure 2) shows regressions weights: warmer in a greenhouse -> climate effects $\beta=.01, p<.89$; what is the greenhouse effect $\rightarrow$ climate effects $\beta=.23$, $p<.001$; and main greenhouse gases - > climate effects $\beta=.07, p<.15$. The model shows that knowing about the greenhouse effect is the strongest predictor of understanding climate change. However, results showed that only $6 \%$ of the variance in correct climate change explanations was explained by this model, indicating that for the majority of students their ideas about climate change were not linked to their understanding of the greenhouse effect, their experience of greenhouse conditions or their knowledge of the main greenhouse gases.

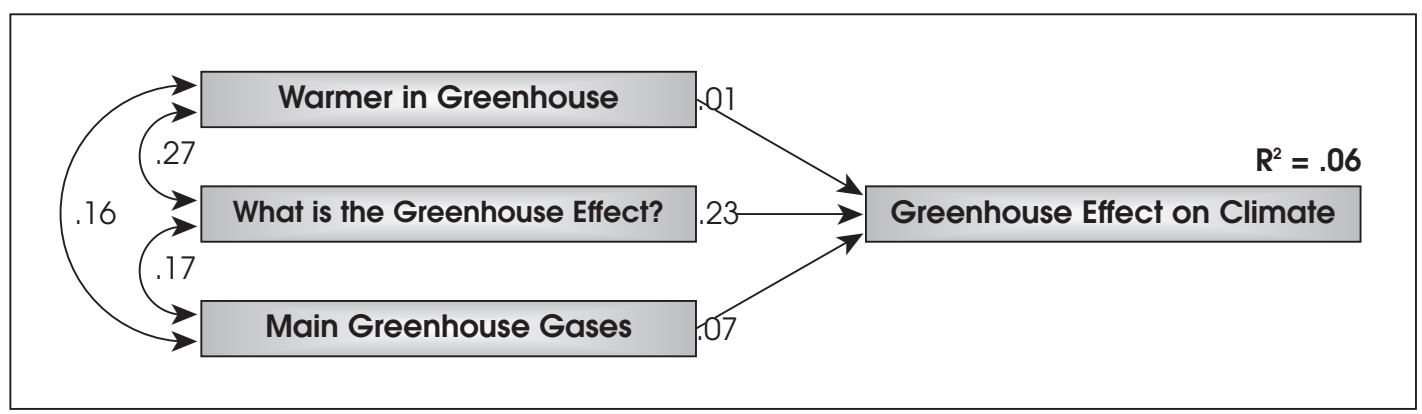

Figure 2: Fitted Model:

Influences guiding the perceptions of the greenhouse effect upon climate change

Human activity and its effect on greenhouse gas emissions was examined next. Here there were few differences between the two groups, with the exception of the case of CFCs. The UK group appears to have significantly more knowledge of these gases' greenhouse effects (Table 1). This might be due to the contextual primacy that was given to these gases around the 1990s. On the other hand, the Australian cohort has a significantly better grasp of the greenhouse effect on rainfall, sunshine and sea levels, possibly reflecting greater consensus about these effects in the scientific community over the last 16 years, or more media coverage of unusual weather patterns. 


\section{HELEN BOON}

The information sources students cited varied (Table 4). The most important difference between the two groups is the citing of school as a source of information: $83 \%$ of Australian compared to only $50 \%$ of UK students cited school as a source of information. Given the majority of Australian students stated that they have been exposed to these issues at school it seems incongruent that in comparison to the UK students they have no more knowledge and/or understanding of them. In some cases, for example in regards to greenhouse effects on the climate, or ozone layer function, their knowledge appears to be less secure than the earlier cohort's. As might be expected, results suggest that although the television still plays an important educating role for students, the internet has now gained primacy for some students, replacing books and magazines as sources of information. Parental influence remains remarkably constant in both student groups illustrating the importance of accurate public knowledge of such issues.

\begin{tabular}{|c|c|c|}
\hline Sources of Ideas & UK students (\%) & Australian students (\%) \\
\hline Parents & 40 & 43 \\
\hline TV & 90 & 68 \\
\hline Radio & 24 & 24 \\
\hline Books/Magazines & 64 & 41 \\
\hline Friends & 36 & 28 \\
\hline Internet & 0 & 49 \\
\hline Don't know/can't remember & 6 & 17 \\
\hline School & 50 & 83 \\
\hline Other & 16 & 5 \\
\hline
\end{tabular}

Table 4: Sources of UK and Australian student ideas and \% of students reporting them

\section{Discussion}

The aims of this study were to compare and contrast two similar student groups separated in time and geography, but operating in similar educational contexts, experiencing unusual weather patterns and media influences for a looming general election. While it could be argued that the two groups cannot be compared due to contextual differences, it is reasonable to expect scientific knowledge accumulated over 16 years to have an impact on raising awareness and understanding about the issues examined here, particularly in educational contexts.

Results suggest there are statistically significant differences between the two groups in their knowledge about why it is hotter inside a greenhouse, the impact of the greenhouse effect upon the climate and the function of the ozone layer. In all these instances the UK students outperformed their Australian counterparts despite the latter having been exposed to these issues at school to a greater extent than the UK students. Given that the study took place in a regional Queensland city, with state 
school students, it is not clear to what extent other Australian students might share the same perceptions, however similar results were obtained by Fisher (1998) in comparing UK and Victorian/ACT students.

Disconfirming hypotheses, there is no significant difference between students in their understanding of what is the greenhouse effect; both seem to be under-informed about this important phenomenon. This is surprising since it was anticipated that with 16 years intervening between the first and second study student understanding would have shown improvements because of greater general awareness about climate change, more emphasis on teaching this topic at school, and a large body of research documenting student misconceptions for teachers to draw upon to assist them in their teaching (e.g., Boyes \& Stanisstreet, 1993; Boyes, Chuckran \& Stanisstreet, 1993; Boyes \& Stanisstreet, 2001).

Possible explanations of findings in both sets of students include:

1. Although some students can understand the physics behind radiation absorption, the more complex interactions between chemical reactions and physical processes taking place in the atmosphere are difficult to assimilate.

2. Students have difficulty remembering material that they have been taught.

3. Students simply misunderstand the processes of the Greenhouse Effect.

4. The Greenhouse Effect has been inadequately covered at school as a whole process.

5. The students are reiterating incomplete information which they may have heard from the media.

6. A combination of all of the above.

Of the above, recall difficulties cannot be said to explain the differences between UK and Australian students. This leaves two broad reasons for findings: students (both UK and Australian) misunderstand the greenhouse effect as a whole and/or they have been insufficiently or inadequately exposed to these ideas at school, leaving them with snippets of information gathered elsewhere.

The former is illustrated by the models of explanation students report. The same models have persisted over 16 years with results echoing those found by previous researchers (e.g., see review Lee, Lester, Ma, Lambert, \& Jean-Baptiste, 2007; Boyes, \& Stanisstreet, 1993, 1997). Whilst students' answers are qualitatively similar, ideas about the ozone layer's implication in the greenhouse effect seem to have decreased 
quantitatively. A proportion of students now say gases are insulating the Earth. However, to what extent this is the result of a lack of general knowledge about the ozone layer's function rather than a use of new models is not clear. Certainly much fewer Australian compared to UK students reported the correct function of the ozone layer. Those who did were very knowledgeable, for example: "It helps prevent UV rays from entering the atmosphere, but if it is too low it can be a greenhouse gas" (Year 10 student). Some students (6\%) appear to believe that pollutant gases are responsible for creating the greenhouse effect, perhaps reflecting general public misconceptions (Dunlap, 1998) or an imprecise use of language, reflecting the idea that pollution causes a range of environmental problems. Media Hype is proposed by $4.5 \%$ of students as another explanation of the greenhouse effect.

It seems that the construction of students' explanations have not been modified in light of better scientific awareness of the phenomena. Moreover, the inclusion of "Media Hype" in their responses indicates that there is some general tendency to disengage from the phenomenon. This disengagement may be the reason behind the low retention of accurate knowledge about the greenhouse effect, since over $80 \%$ of the Australian group reported having been exposed to these issues at school. SEM modelling showed that knowledge of the greenhouse effect, main greenhouse gases and greenhouse function does not predict a clearer understanding of climate change even though $55.8 \%$ of students displayed accurate knowledge of climate effects. This suggests students may have constructed their ideas independently of teaching influences, the greenhouse effect has not been appropriately taught as a whole process or teachers from various integrated school subjects have contributed to student knowledge (e.g., science, SOSE).

There might be several reasons for this. The simplest one relates to the sources of information students access. Whilst acknowledging a limitation of the questionnaire design which did not allow students to cite sources for particular aspects of their knowledge, it is nevertheless pertinent to make conjectures about their sources as a whole.

First, television and the Internet may present data on climate effects without explanations of the science behind the phenomena. Droughts, floods and hurricanes may be simply depicted as results of climate change. This is not an unreasonable assumption given the science of climate change and the greenhouse effect is very complex (Kerr \& Walz, 2007; Schreiner, Henriksen, \& Kerkeby Hansen, 2005).

Second, teaching at school may have had little impact upon students because they have already constructed views about these issues, based on media reporting other societal influences such as the political stance of the government. Some studies reviewing the content of media information on climate change found media sources 
often express uncertainty about the causes and occurrence of global warming (Dispensa \& Brulle 2003), and a pro-corporate bias (Nissani, 1999). Thus if a student, or their parent, has primarily learned about climate change from newspapers and television reports, s/he may not be aware of views of mainstream science. The efforts of conservatives and some industrial sectors, such as the fossil fuel industry, to shape the political elite and the media debate about climate change in the US are well documented. These efforts contribute to media coverage with a pro-corporate bias, emphasizing uncertainty, leaving lay people potentially confused and apathetic about climate change (Dispensa \& Brulle 2003; McCright \& Dunlap 2000, 2003). The extent of such a bias in Australia is uncertain.

Third, the perceived urgency of climate change also shapes public engagement with it. As Stanwell-Smith (2007) contends, "One of the many difficulties in getting to grips with climate change is the inevitably long-term projections. 2080s - not many of us that bothered; 2050s - still a long way off; 2011 - now you've got our interest" (p. 3). Perhaps disengagement due to the perceived remoteness of the effects of climate change underscores some students' responses.

Bronfenbrenner (1979) claims the macrosystem, wherein individuals develop, has important influences upon perceptions. The macrosystem is defined as the fabric of society, its current views and prevailing perspectives. Studies support situational influences upon students' beliefs and engagement with climate change (DevineWright, Devine-Wright, \& Fleming, 2004; Uzzell, 1999). In Australia, there has been a long period of denial expressed by the governing political bodies regarding the impact of the greenhouse effect and the anthropogenic generation of greenhouse gases upon climate; a view that was a reflection of the dominant US stance. The Bush Administration has blocked action on global warming world-wide, questioning and occasionally suppressing compelling scientific evidence showing the Earth is heating up because of man-made greenhouse gas emissions (Walsh, 2008). The extent to which this has impacted upon Australian teachers' pedagogy and values can only be guessed at, though studies indicate knowledge about the causes of global warming predicts people's behavioural intentions (e.g., O'Connor, Bord, \& Fisher, 1999). Individuals who are misinformed about the causes of climate change are perhaps unlikely to support policies, or take individual action, to mitigate greenhouse gas emission effects. Teachers who are misinformed, disbelieve the urgency of climate change or whose scientific knowledge is not regularly updated, are also less likely to encourage debate and consideration of these issues in class. Waters-Adams (2006) reported that "ideas, beliefs, and values have all been recognized as integral elements of (teacher) action" (p. 920), and found that the teachers' understanding of science affected their practice. Howitt (2007) found Australian primary teachers' lack of confidence in science led to the avoidance of science teaching, Further, King (2007) 
found if Queensland teachers valued the context-based chemistry syllabus they were more likely to overcome constraints in its implementation, highlighting the role of personal beliefs in teaching.

There is substantial evidence that teacher understanding of the greenhouse effect is inadequate for teaching it (Boyes \& Stanisstreet, 1992; Dove, 1996; Fortner, 2001; Hansen, 2003). Moreover, the mode of teaching science adopted by the majority of teachers, one of transmissive pedagogy, is not necessarily the most conducive to student engagement (Lyons, 2005). Transmissive pedagogy techniques are not as effective when teachers are ill prepared to teach topics such as the greenhouse effect, due to misconceptions about the science behind the phenomenon (Dove, 1996; Jeffries, Stanisstreet \& Boyes, 2001; Kerr \& Walz, 2007). They are also ineffective when teacher resources, texts and teaching strategy manuals, do not fully incorporate the greenhouse effect and climate change and when teachers do not base their teaching upon "an appreciation of the preconceptions and misconceptions of those to be taught, about students' ideas in this area" (Boyes, Chuckran, \& Stanisstreet, 1993, p. 556). Taking a constructivist approach requires teaching to be built upon students' existing knowledge and their frames of reference.

Another important aspect of successful engagement is the relevance of the topic to the learner. Osborne and Collins (2001) found students perceived school science to be irrelevant. They concluded teachers too infrequently attempted to link science concepts to everyday life. Perhaps this is another reason why the UK students performed somewhat better than their Australian counterparts: the topic was relatively novel, attracting much media attention and, in the UK at the time, there was consistent political acceptance of the causal links between global warming and increased greenhouse gas emissions and support for policies to mitigate the effects. This has not been the case in Australia.

Unfortunately, because of greater experience with the devastating effects of cyclones and other natural disasters, educators today have more data than ever to make the topic relevant and maintain student engagement. Typically, personal energy use and consideration of alternative energy sources or drought and biodiversity reduction resulting from ecosystem changes might be scenarios for engaging students in relation to climate change. Now as a result of heat waves and floods we can also include health effects that ensue from such events. Examples that Stanwell-Smith (2007) cites are: extreme weather events (heatwaves, floods) resulting in deaths; increases in gastrointestinal infection; the threat of malaria returning to parts hitherto free from it; skin cancers from higher sun exposure/less cloud cover; the emergence of new insect vectors and pests; food poisoning increases by around 4,000 additional notifications with an increase in global temperature of only $1^{\circ} \mathrm{C}$, expected within the next 20 years, 
to name a few. There are also options of engaging students in political scenarios. In the US, national security is seen as corollary of climate change with rising sea levels and super-storms presenting physical danger, but also resource wars for fossil fuels and refugees fleeing drought and famine (Walsh, 2008). Finally, to design effective learning experiences teachers need to consider:

How to make ideas compelling and understandable to learners; what a psychological or learning-based account of these ideas would entail; what kinds of experiences would help learners develop these ideas, and what kinds of reasoning tasks would represent the use of this knowledge. (Krajcik, McNeill, \& Reiser, 2008, p. 3)

While teachers play a key role in this particular scientific literacy issue, there is evidence of what Bronfenbrenner (1979) calls macrosystem effects. For example, government and media acting together to enhance public awareness for environmental issues. In the UK, government and the media have been more successful in promoting scientifically and environmentally literate citizens independently and through education. As a result, UK university students are better informed about environmental issues, such as climate change, than their US counterparts (Spellman, Field, \& Sinclair, 2003). Macrosystem effects permeate all levels of operation in organisations such as schools. Evidence from an ethnographic study suggests student outcomes "frequently do not arise within and from the lived world of students and teachers, but from the organisation and articulation of academy, school, and school board levels" (Roth, Tobin, \& Ritchie, 2008, p. 139). The implication is that teachers and students are players in a much larger, complex arena. Student knowledge and understanding is unlikely to be improved simply by including a curriculum topic or increasing teacher preparation. Roth et al. (2008) claim what is required is an understanding of how teaching and learning are mediated by the organisational relations between classrooms, schools, and school boards, universities and governing administrations, the very cultural fabric of society, as well as temporal contingencies required to make changes possible. This view concurs with Bronfenbrener's theory (1979) and perhaps offers an explanation for findings in this study, which suggest that government and media stances might have influenced the perceived importance of teaching (and learning about) the greenhouse effect within the time frame advocated by scientists studying the phenomenon.

In conclusion, while OECD (2007) scientific literacy results place Australian students near the top of the league of participating countries, this study provides evidence that this may not be the case for regional Australian students. Even if current results are an improvement over previous years for Australian students, they are clearly not yet adequate for informed citizenship participation. Given the recent change in federal government in Australia it is anticipated that there will be more encouragement for 
everyone to engage with the ramifications of the greenhouse effect and for teachers, and educational organizations in general, to better inform, encourage and empower youth to meet and respond to future challenges.

\section{Acknowledgements}

This research was supported by the SiMERR, The National Centre of Science, Information and Communication Technology, and Mathematics Education for Rural and Regional Australia

\section{References}

Australian Bureau of Statistics (ABS). (1998). Environmental issues: People's views and practices. Canberra: Australian Bureau of Statistics.

Australian Bureau of Statistics (ABS). (1999). Environmental issues: People's views and practices. Canberra: Australian Bureau of Statistics.

Arbuckle, J. L., \& Wothke, W. (1999). Amos 4.0 users' guide. Chicago: SmallWaters.

Barr, S. (2007). Factors influencing environmental attitudes and behaviours: a UK case study of household waste management. Environment and Behaviour, 39(4), 435-473.

Baron, R. M., \& Kenny, D. A. (1986). The moderator-mediator variable distinction in social psychological research: Conceptual, strategic, and statistical considerations. Journal of Personality and Social Psychology, 51(6), 1173-1182.

Berk, R. A., \& Schulman, D. (1995). Public perceptions of global warming. Climatic Change 29, 1-33.

Bollen, K. A. (1989). Structural equations with latent variables. New York: Wiley.

Boyes, E., Chuckran, D., \& Stanisstreet, M. (1993). How do high school students perceive global climatic change: What are its manifestations? What are its origins? What corrective action can be taken? Journal of Science Education and Technology, 2(4), 541-557.

Boyes, E., \& Stanisstreet, M. (1992). Students' perceptions of global warming. International Journal of Environmental Studies, 42, 287-300.

Boyes, E., \& Stanisstreet, M. (1993). The greenhouse effect: Children's perceptions of causes, consequences and cures. International Journal of Science Education, 15(5), 531-552.

Boyes, E., \& Stanisstreet, M. (1997). Children's models of understanding of two major environmental issues (ozone layer and greenhouse effect). Research in Science and Technological Education, 15, 18-28.

Boyes, E., \& Stanisstreet, M. (2001). Global warming: What do high school students know 10 years on? World Resource Review, 13(2), 221-238. 
Bronfenbrenner, U. (1979). The ecology of human development: experiments by nature and design. Cambridge, MA: Harvard University Press.

Coffield, F., Edward, S., Finlay, I., Hodgson, A., Spours, K., Steer, R., \& Gregson, M. (2007). How policy impacts on practice and how practice does not impact on policy. British Educational Research Journal, 33(5), 723-741.

Conservative Party. (1992). The best future for Britain: 1992 Conservative Party general election manifesto. Retrieved January 2, 2008, from http://www.conservativeparty.net/manifestos/1992/1992-conservative-manifesto.shtml

Cordero, E. C. (2001). Is the ozone hole over your classroom? Australian Science Teachers' Journal, 48(1), 34-39

Devine-Wright, P., Devine-Wright, H., \& Fleming, P. (2004). Situational influences upon children's beliefs about global warming and energy. Environmental Education Research, 10(4), 493-506.

Dispensa, J .M., \& Brulle, J. R. (2003). Media's Social Construction of Environmental Issues: Focus on Global Warming-A Comparative Study. International Journal of Sociology and Social Policy, 23, 74-105.

Dove, J. (1996). Student-teacher understanding of the greenhouse effect, ozone layer depletion and acid rain. Environmental Education Research, 2(1), 89-100.

Driver, R., Asoko, H., Leach, J., Mortimer, E., \& Scott, P. (1994). Constructing scientific knowledge in the classroom. Educational Researcher, 23, 5-12.

Dunlap R. E. (1998). Lay perceptions of global risk public views of global warming in cross-national context. International Sociology, 13(4), 473-498.

Environment Protection Authority (EPA). (2000). Who Cares About the Environment? A Community Survey. NSW: Taverner Research Company.

Fisher, B. (1998). Australian students' appreciation of the greenhouse effect and ozone hole. Australian Science Teachers Journal, 44(3), 46-55.

Fortner, R. W. (2001). Climate change in school: Where does it fit in and how ready are we? Canadian Journal of Environmental Education, 6, 18-31.

Fortner, R., Lee, J., Corney, J., Romanello, S., Bonnell, J., Luthy, B., et al. (2000). Public understanding of climate change: Certainty and willingness to act. Environmental Education Research, 6(2), 127-141.

Hansen, P. J. K. (2003, July). The greenhouse effect and the effects of the ozone layer: Norwegian teacher students' development of knowledge and teaching skills. Paper presented at the EWOC 2003: VI International Conference on School and Popular Meteorological and Oceanographic Education, Departamento de Física, Universidad Europea de Madrid, Spain.

Howitt, C. (2007). Pre-service elementary teachers' perceptions of factors in an holistic methods course influencing their confidence in teaching science. Research in Science Education, 31(1),41-58. 


\section{HELEN BOON}

Intergovernmental Panel on Climate Change (IPCC). (2007). Climate Change 2007: Synthesis Report, Summary for policy makers. Retrieved January 12, 2008, from http://www.ipcc.ch/pdf/assessment-report/ar4/syr/ar4_syr_spm.pdf

Jeffries, H., Stanisstreet, M., \& Boyes, E. (2001). Knowledge about the "Greenhouse Effect": have college students improved? Research in Science \& Technological Education, 19(2), 205-221.

Joreskog, K. G., \& Sorbom, D. (1984). LISREL VI: analysis of linear structural relationships by the method of maximum likelihood (3rd ed.). Mooresvile, IN: Scientific software.

Kerr, S. C., \& Walz, K. A. (2007). "Holes" in student understanding: Addressing prevalent misconceptions regarding atmospheric environmental chemistry. Journal of Chemical Education, 84(10), 1693-1696.

King D. (2007). Teacher beliefs and constraints in implementing a context-based approach in chemistry. Teaching Science, 53(1), 14-18.

Khilyuk, L. F., \& Chilingar, G. V. (2003). Global warming: Are we confusing cause and effect? Energy Sources, 25, 357-370.

Krajcik, J., McNeill, K. L., \& Reiser, B. J. (2008). Learning-goals-driven design model: Developing curriculum materials that align with national standards and incorporate project-based pedagogy. Science Education, 92, 1-32.

Lee, O., Lester, B. T., Ma, L., Lambert, J., \& Jean-Baptiste, M. (2007). Concepts of the greenhouse effect and global warming among elementary students from diverse languages and cultures. Journal of Geoscience Education, 55(2), 117-125.

Lowe, I. (2000). A changing climate. New Scientist, 2256, 52.

Lyons, T. (2005). Different countries, same science classes: Students' experiences of school science in their own words. International Journal of Science Education, 28(6), 591-614.

Massarani, L., \& Castro Moreira, I. (2005). Attitudes towards genetics: A case study among Brazilian high school students. Public Understanding of Science, 14, 201-212.

MacCallum, R. C., \& Austin, J. T. (2000). Applications of structural equation modelling in psychological research. Annual Revue of Psychology, 51, 201-226.

McCright, A., \& Dunlap, R. E. (2000). Challenging global warming as a social problem: An analysis of the conservative movement's counter-claims. Social Problems, 47, 499-522.

McCright, A., \& Dunlap, R. E. (2003). Defeating Kyoto: The conservative movement's impact on U.S. climate change policy. Social Problems 50, 348-73.

Maruyama, G. M. (1998). Basics of structural equation modelling. Thousand Oaks, CA: Sage.

Muthen, B. O. (1984). A general structural equation model with dichotomous, ordered categorical and continuous latent indicators. Psychometrika, 49, 115-132.

Nissani, M. (1999). Media coverage of the greenhouse effect. Population and Environment, 21, 27-43. 
Morgan, M. D., \& Moran, J. M. (1995). Understanding the greenhouse effect and the ozone shield: an index of scientific literacy among university students. Bulletin of the American Meteorological Society, 76/7, 1185-90.

O'Connor, R. E., Bord, R. J., \& Fisher, A. (1999). Risk perceptions, general environmental beliefs, and willingness to address climate change. Risk Analysis, 19, 461-471.

Organisation for Economic and Cooperative Development (OECD). (2007). PISA 2006 Volume 2: Data??/Données. Retrieved December 12, 2007, from www.sourceoecd.org/ education/9789264040144

Osborne, J., \& Collins, S. (2001). Pupils' views of the role and value of the science curriculum: A focus-group study. International Journal of Science Education, 23(5), 441-467.

Papadakis, E. (2002). Global environmental diplomacy: Australia's stances on global warming. Australian Journal of International Affairs, 56(2), 265-277.

Pierce, C. A., Block, R. A., \& Aguinis, H. (2004). Cautionary note on reporting etasquared values from multifactor ANOVA designs. Educational and Psychological Measurement, 64(6) 916-924.

Queensland Studies Authority (QSA). (1999). Science: Years 1-10 syllabus. Brisbane, QLD: QSA.

Queensland Studies Authority (QSA). (2000). Science: Years 1-10 syllabus. Brisbane, QLD: QSA.

Roth, W-M., Tobin, K., \& Ritchie, S. M. (2008). Time and temporality as mediators of science learning. Science Education, 92, 115-140.

Ryder, J. (2001). Identifying science understanding for functional scientific literacy. Studies in Science Education, 36, 1-44.

Schreiner, C., Henriksen, E., \& Kerkeby Hansen, P. J. (2005). Climate education: Empowering today's youth to meet tomorrow's challenges. Studies in Science Education, 41(1/2), 3-50.

Skamp, K. (2000). Environmental concepts: Important and neglected? In Australian Association for Environmental Education: International conference on environmental change (pp. 103-118). Manly, NSW: Australian Association for Environmental Education.

Spellman, G., Field, K., \& Sinclair, J. (2003). An investigation into UK higher education students' knowledge of global climatic change. International Research in Geographical and Environmental Education, 12(1), 6-17.

Stanwell-Smith, R. (2007). All change on climate change or more hot air [Electronic version]? Health and Hygiene, 28(3), 2-5.

Terry, P. (2007). Climate change technology could be hindered by public attitude, says scientist. Retrieved January 25, 2008, from http://www.sciencewa.net.au/index.php? option $=$ com_content\&task $=$ view\&id $=551 \& I t e m i d=587$ 


\section{HELEN BOON}

Tytler, R. (2007). Australian education review. Re-imaging science education: Engaging students in science for Australia's future. Camberwell, Vic: Australian Council for Educational Research.

Tytler, R., \& Symington, D. (2006). Science in school and society. Teaching Science: The Journal of the Australian Science Teachers Association, 52(3), 10-15.

Uzzell, D. (1999). Education for environmental action in the community: New roles and relationships. Cambridge Journal of Education, 29, 397-413.

Walsh, B. (2008). Wind shift [Electronic Version]. Time International, 171(4), 56.

Waters-Adams, S. (2006). The relationship between understanding of the nature of science and practice: The influence of teachers' beliefs about education, teaching and learning. International Journal of Science Education, 28(8), 919-944.

Weaver, A. A. (2002). Determinants of environmental attitudes: A five-country comparison. International journal of sociology, 32(1), 77-108.

Wilson, K., \& Henson, B. (1993). Learning about Global Warming: A Study of Students and Journalists. [Learning about Science Easily and Readily series.] Boulder, CO: National Centre for Atmospheric Research. 


\section{CLIMATE CHANGE? WHEN? WHERE?}

\section{Appendix \\ Survey questions: CIRCLE YOUR ANSWER}

Do you identify as Indigenous? Yes/No Year: 8/10 Gender: M/F

1 a) Have you ever been in a green house on a warm summer's day? (Yes/No)

b) Do you think it is warmer or cooler inside a greenhouse than outside? (warmer/cooler/the same/don't know)

c) Can you think of any reason why this should be so? Please write your ideas in the space provided.

Scientists say that the climate is slowly changing and that this is caused by 'the greenhouse effect'. It is known that some gases in the atmosphere are responsible for the 'greenhouse effect'. They are called 'greenhouse gases'.

2 a) Which of the following do you think is the main 'greenhouse gas'? (oxygen/carbon dioxide/nitrogen)

b) Do you know any other 'greenhouse gases'? Please write them down.

3 a) What do you think the 'greenhouse effect' is? Write down your ideas

b) How does it affect the climate? Write down your ideas.

4 What do you think the effects of a warmer climate will be?

a) The sea levels will ... (rise/fall/stay the same/don't know)

b) Rainfall will be ... (higher in most places/lower in most places/lower in some places and higher in others/ the same in most places/don't know)

c) Sunshine ... (more sunshine in most places/less sunshine in most places/less in some places and more in others/ the same in most places/don't know)

d) Farmers crops will be ... (generally better/generally worse/stay the same/don' $t$ know)

e) The ice caps in the North and South Poles will ... (get bigger/get smaller/stay the same/don't know)

It is known that human activity produces greenhouse gases. Will the following activities tend to increase or decrease the amount of these gases in the atmosphere?

5 a) Burning oil or coal for fuel (increase/decrease/don't know)

b) Planting trees and forests (increase/decrease/don' $\dagger$ know)

c) Making and using CFCs (increase/decrease/don'† know)

d) Using alternative energy sources such as solar power and wind (increase/decrease/don' $†$ know)

e) Insulating buildings to prevent heat loss/gain (increase/decrease/don'† know)

f) Using motor cars (increase/decrease/don't know)

6 a) Have you heard of the 'Ozone layer'? (Yes/No)

b) If yes, what do you think the ozone layer does? Write down your ideas.

7 Where did your ideas and knowledge to answer this survey come from? You may tick more than one source.
$\square$ Taught at school
Parents
$\square$ Radio
$\square$ Internet
Books/magazines
$\square$ Other
Talking to friends
Don'† know/can't remember 
